\title{
El Diccionario de los voluntarios austriacos en
}

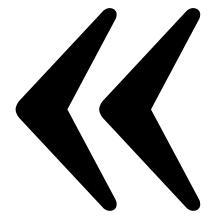

El número de combatientes en España todavía con vida va disminuyendo. Pronto se nos podrá contar con los dedos de una mano. Por eso me urgía concluir el diccionario. Está pensado para una breve eternidad, como un legado en vida y como un fundamento bastante sólido para cualquier obra posterior sobre los voluntarios austriacos que defendieron la República Española. A sus autores les espera un trabajo más sencillo y, a la vez, más difícil, pues ellos ya sólo trazarán nuestra historia, ya no serán protagonistas de ella»-dice Hans Landauer al final de su introducción a esta conmovedora obra sobre los casi mil cuatrocientos austriacos que viajaron a España para defender la democracia y luchar contra el fascismo. El hecho en sí ya es poco conocido, tanto en Austria como en España, y apenas ha sido investigado en nuestro país. Poder leer los resultados de una investigación que se extiende sobre varias décadas y que, además de un listado alfabético de los brigadistas y voluntarios relacionados las Brigadas Internacionales, incluye una amplia introducción de Hans Landauer con la colaboración del escritor Erich Hackl (autor de Auroras Anlass, Abschied von Sidonie, Sara und Simon, Hochzeit in Auschwitz...), es un auténtico privilegio.

En la espléndida introducción aprendemos y nos sorprendemos, a menudo con el corazón en un puño, con incontables datos e informaciones de primerísima mano: desde la organización del viaje a España, la mayoría de las veces de manera clandestina a través de organizaciones ubicadas en Suiza (Basilea y Zúrich) o en París, hasta el sistema de correo clandestino que idearon algunos para comunicarse con los familiares en Aus-

\author{
ISABEL GARCÍA ADANEL \\ Universidad de Alcalá
}

tria, las diversas fases de movilización y traslado a España, la organización de los batallones por grupos lingüísticos, el servicio de Sanidad que crearon los extranjeros en pueblos españoles, la participación de numerosas mujeres profesionales de estos campos o el dilema de la mayoría de combatientes al disolverse las Brigadas y terminar la guerra: ¿Adónde regresar cuando los países de origen habían dejado de existir, como fue el caso de las repúblicas austriaca, checa, eslovaca, polaca o yugoslava, desaparecidas tras la invasión de los nazis? Nos estremecemos también al leer sobre el trágico destino de muchos de ellos, por ejemplo, de los
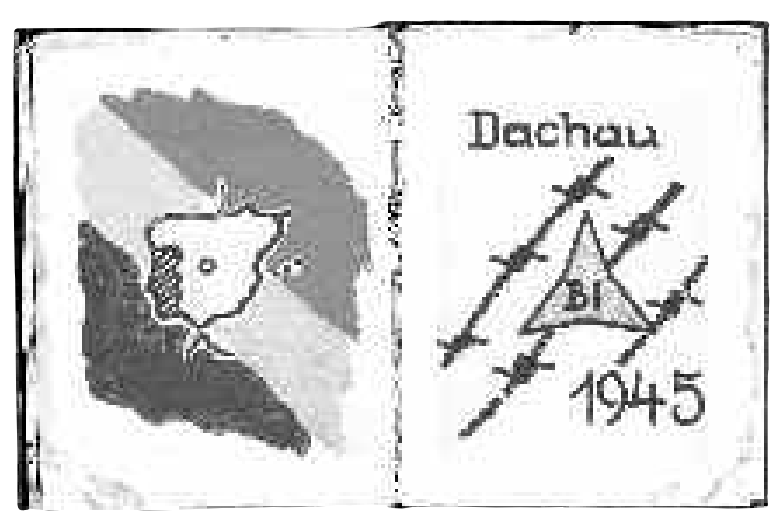

contra Alemania, algunos fueron arrestados allí más adelante y aún fueron confinados al gulag. Todo ello, por supuesto, incluyendo nombres, cifras y lugares detallados. Incluso se proporcionan los nombres en clave utilizados por determinadas personas durante la guerra ( García, Jakob Maximilian es: Weber, Karl; Goldstaub, Otto es: Dobias, Karl, etc.).

Pero los nombres dejan de ser simples nombres y cifras (y ya no es poco seguir su rastro y recogerlo por escrito) para convertirse en individuos. Siguiendo un riguroso sistema en la organización de cada ficha, se intenta recoger de cada uno de los voluntarios: apellido, nombre, lugar y fecha de nacimiento, profesión aprendida o ejercida antes de llegar a España, nombre falso en España de haberlo, relaciones de parentesco con otros brigadistas de haberlas, filiación política anterior de haberla, fecha de llegada a España, destino, etapas posteriores a España (entre 1939 y 1945 en los casos normales), actividades y lu-

que regresaron al territorio alemán, arrestados "por principio" por haber luchado contra el fascismo en España y internados en campos de concentración nazis (como es el caso del propio Hans Landauer y también de muchos españoles, compañeros antifascistas, que viajaron a Alemania por no quedarse en España... y terminaron igualmente en Dachau). Otros se exiliaron en Inglaterra o marcharon a la Unión Soviética para luchar gar de residencia posterior.

En unos casos se llenan todas las casillas de la ficha, se conoce la trayectoria hasta el presente y se puede documentar una vida larga, más o menos normal y un fallecimiento en circunstancias más o menos «pacíficas», tras haber vivido la posguerra y la democracia e incluso la caída del comunismo. En otros, por el contrario, se han encontrado muy poco datos sobre la procedencia o sobre el paradero 


\section{la España republicana 1936-1939}

Todo en esta obra es especial (empezando por

su peculiar formato cuadrado) y se percibe en

ella, además de un admirable rigor histórico y

cientificico en la investigación, un gran amor ha-

(o sobre ambas cosas) de la persona, y bien la pertenencia a las Brigadas Internacionales bien el posterior destino queda en una «zona gris entre la cer-

ciaquienessllenansuspáginasyporlacausaque

defendieron en España.

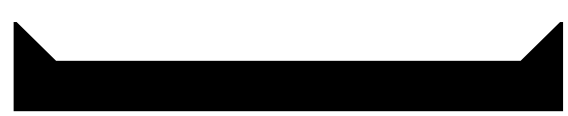

teza y la suposición» (Landauer, pág. 61). En un tercer caso, no son escasos los datos, sino lamentablemente las vidas de las personas, que cayeron ya en España o nada más regresar a sus países de origen ( «Dworak, Leopold. Nace en Atzgersdorf (Viena) el 13 de noviembre de 1909. Caído en Quijorna el 9 de julio de 1937» (pág. 92). «Schmidt, Robert. Nace en Viena el 5 de septiembre de 1912. Ayudante de montador. El 27 de enero de Austria a España. XV BI. Muere en el hospital de Benissa en 1938 (pág. 225)). Todos ellos personas reales. Vidas reales... y muertes reales en los frentes españoles.

Todo en esta obra es especial (empezando por su peculiar formato cuadrado) y se percibe en ella, además de un admirable rigor histórico y científico en la investigación, un gran amor hacia quienes llenan sus páginas y por la causa que defendieron en España. La edición española, además, está realizada con enorme cuidado: con un prólogo redactado ex profeso para esta edición (G. Pichler) y siempre teniendo en cuenta el desconocimiento de los lectores sobre la realidad austriaca de la época. La traducción, nada fácil en sí y con el problema añadido de tener que buscar muchos equivalentes para conceptos y categorías que no existen en español ni en España, hace honor al resto de la obra.

Complementan los textos numerosas fotografías de todas las épocas posibles (combatientes descansando y sonrienmapa de Austria (en el original es un mapa de España y de las principales zonas en las que lucharon las Brigadas Internacionales lo que se ofrece al lector, en este caso desconocedor de nuestra geografía) $y$, al final un glosario -más completo que el de la edición original teniendo en cuenta la necesidad de ofrerra Mundial. siguen con vida...) y también imágenes de documentos como permisos de identidad, permisos de residencia y alguna curiosidad, como el resguardo de la indemnización del Banco Soviético a un brigadista por haber estado doce años internado en el gulag.

Al comienzo encontramos también un

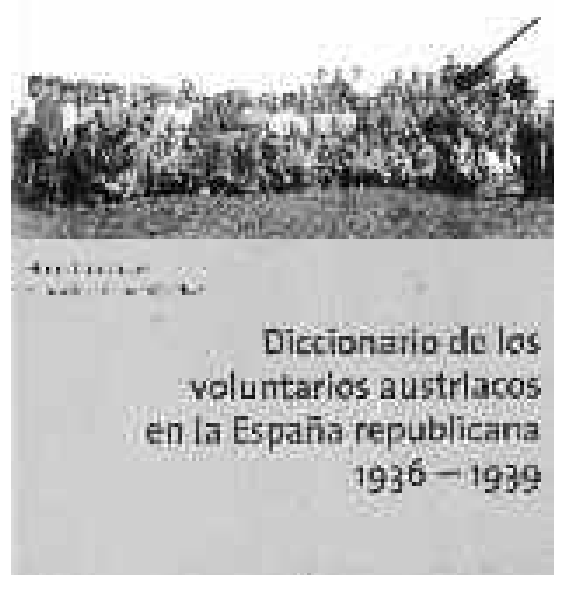

ñoles del campo de concentración de $\mathrm{Da}$ chau confeccionaron para Hans Landauer cuando el campo fue liberado y en el que firmaron todos como despedida.

Sin lugar a dudas, se trata de una obra fundamental para cualquiera, un conmovedor y digno homenaje a la memoria de todos esos héroes que, gracias a la labor de investigación que recoge este diccionario, han dejado de ser anónimos; una llamada a tomar conciencia de nuestra propia historia -y también de la vergonzante falta de heroísmo y solidez de valores que impregna la actualidad-: y un admirable testimonio de la valía humana de quienes protagonizaron esta historia -más aún si cabe, de quien no sólo la protagonizó, sino que ha dedicado gran parte de su vida a su documentación y conservación para poder ofrecernos este «legado» inestimable.

Para adquirir ellibro, eso sí, es necesario recurrir a la propia Asociación de Amigos de las Brigadas Internacionales (C/Campomanes cer ciertos datos a los lectores españoles-, un índice de lugares y una tabla cronológica que abarca desde el 12-14 de abril de 1931, la proclamación de la República en España, hasta el 1 de septiembre de 1939, inicio de la Segunda Gue-

Como colofón, el diccionario incluye un documento absolutamente estremecedor y de inestimable valor: el facsímil de un tosco cuadernillo que los presos espa-
8, 28013 Madrid; en: aabi@tinet.org, o en www.brigadasinternacionales.org), pues no ha tenido distribución en las librerías normales. En Austria, lleva tiempo agotada la edición original.

[1]. Madrid, 2005; 284 páginas; edición e introducción de Hans Landauer en colaboración con Erich Hack1; traducción de Bettina Linares. ISBN: 84-609-7269-0. 